\title{
A PRODUÇÃO SOCIAL DO INIMIGO: O DIREITO COMO DISCURSO LEGITIMADOR DA VIOLÊNCIA SIMBÓLICA
}

\section{LA PRODUCTION SOCIALE DE L'ENNEMI: LE DROIT COMME DISCOURS DE LÉGITIMATION DE LA VIOLENCE SYMBOLIQUE}

\author{
${ }^{1}$ Abili Lazaro Castro De Lima \\ ${ }^{2}$ Guilherme Milkevicz
}

\section{RESUMO}

O medo e a insegurança rondam as subjetividades de nosso tempo. Vivemos uma época "pósideológica", que afirma ter superado os perigos do engajamento político radical; uma sociedade que se pretende liberal, tolerante e hedonista. $\mathrm{O}$ curto-circuito é inevitável, pois as medidas assumidas para a manutenção dessa tolerância têm demolido a utopia que julgam defender. Os dispositivos de segurança e controle estão por toda parte e, em vez de assegurarem o cidadão, criam um clima de medo permanente. $\mathrm{O}$ amedrontamento exasperado fortalece os processos sociais de estigmatização e rotulação. Em nome da segurança da sociedade, sacrificam-se os direitos dos cidadãos; o infrator de regras sociais é percebido como inimigo a ser combatido. O presente artigo é uma investigação criminológica sobre as circunstâncias em que o inimigo da sociedade é produzido.

Palavras-chave: Inimigo, Violência, Labeling approach, Medo, Vigilância

\section{RÉSUMÉ}

La peur et l'insurence ronde les subjectivités de notre temps. Nous vivons une époque «postidéologique», qui prétend avoir surmonté les dangers d'engagement politique radical; une société qui a l'intention d'être libérale, tolérante et hédoniste. Le court-circuit est inévitable, car les mesures prises pour maintenir cette tolérance ont démoli l'utopie que juge-avocat. Les dispositifs de sécurité et de contrôle sont partout et, au lieu de assurer le citoyen, créent un climat de peur constante. L'intimidation exaspéré renforce les processus sociaux de stigmatisation et de l'étiquetage. Au nom de la sécurité de la société, sont des droits des citoyens sacrifiés; le délinquant est perçu comme un ennemi à combattre. Cet article est une enquête criminologique dans les circonstances dans lesquelles l'ennemi de la société est produit.

Mots-clés: Ennemi, Violence, Labeling approach, Peur, Vigilance

\footnotetext{
1 Doutor em Direito pela Universidade Federal do Paraná - UFPR, Curitiba - PR (Brasil). Professor da Universidade Federal do Paraná - UFPR, Curitiba - PR (Brasil).

E-mail: abili-lima@uol.com.br

${ }^{2}$ Mestre em Direito pela Universidade Federal do Paraná - UFPR, Curitiba - PR (Brasil).

E-mail: guilhermemilkevicz@gmail.com
} 


\section{INTRODUÇÃO}

A insegurança é o mal-estar ideológico no proêmio do século XXI. A sensação de correr algum tipo de perigo é profusa e diferida no cotidiano das pessoas. Banalizada, generalizada, a insegurança conquistou posições importantes sob a forma de teorias da sociedade de risco, cuja pretensão é refletir a respeito dessa sociedade do imponderável, em que o mal insondável está na iminência do ataque. Temerosa, a sociedade de risco almeja hipermodernizar-se, potenciar aquilo que confere densidade à modernidade: as capacidades de previsibilidade e cauculabilidade (pensando com Weber o "desencantamento do mundo"), ou, numa palavra, a ansiedade por controle. Complexidade e contingência, enfatizadas por Luhmann, são as indeléveis características de uma sociedade de risco demandante de instrumentos hábeis a conter o perigo da indeterminação.

Indissociável deste contexto simultaneamente real e imaginário, emergem iniciativas tecnológicas visando viabilizar o mapeamento cognitivo de tantos aspectos da vida quanto os bancos de dados sejam capazes de suportar - uma iniciativa arrematada por Foucault sob o nome de biopolítica. Agamben capta com precisão o movimento de síntese de opostos, o momento apenas aparentemente paradoxal em que insegurança e dispositivos de segurança e controle se amalgamam perfeitamente. É notável que o cidadão das democracias pósindustriais, na era dita "pós-ideológica", consinta passivamente com inúmeros regramentos nos diversos âmbitos de sua vida (saúde, alimentação, prazeres, gostos etc.), sem que isso provoque qualquer sentimento de alienação ou revolta. Observador minucioso dos ditames do poder, sempre pronto a colaborar, esse sujeito cujos desejos são "comandados e controlados por dispositivos até os mínimos detalhes, é considerado pelo poder - talvez exatamente por isso - como um terrorista virtual" (AGAMBEN, 2014, p. 50).

Constitui-se um perverso ciclo de retroalimentação entre dispositivos e insegurança à medida que os dispositivos securitários operam como signos da insegurança; a ubiquidade do controle mediante dispositivos introjeta a sensação de que há um perigo iminente a ser contido, do contrário, em estado paz plena, não haveria justificativa para vigiar cada movimento dos cidadãos. Hans Kelsen (2012), na Teoria Pura do Direito, assevera que a norma jurídica reguladora do conteúdo da conduta dos agentes sociais é desnecessária se aqueles submetidos à norma estiverem espontaneamente dispostos a obedecê-la; ou seja, a norma jurídica sempre supõe sua violação como pressuposto para incidência: aonde há norma 
jurídica há infração (suposta), indefectivelmente. A presença de dispositivos de controle, analogamente, delata a expectativa de uma conduta infratora, fato que intensifica a sensação de insegurança.

Amiúde, falar em dispositivos evoca imediatamente imagens tecnológicas cuja síntese imagética mais bem acabada é a onipresente câmera de vigilância ${ }^{1}$. Para o termo "dispositivo", Agamben sugere uma definição muito mais ampla; propõe cindir todo o existente em viventes e dispositivos. Por conseguinte, os dispositivos estão disseminados por toda a vida, eles são tudo aquilo capaz de capturar a vida e constituir subjetividade. Para Agamben o sujeito emerge no embate entre viventes e dispositivos, é a resultante desta interação ${ }^{2}$. Por intermédio dessa compreensão, podemos nos aproximar das normas, intitutos e instituições jurídicas como dispositivos de conformação da vida, como componentes de uma extensa máquina governamental da qual todo o arcabouço jurídico faz parte.

Importa-nos traçar algumas linhas concernentes à gênese social do inimigo, da produção de um ator social que, no embate com os dispositivos, é constituído como subjetividade desviante. Fator periclitante, esse ator é definido como inimigo do social e, como tal, merece ser vigiado, procurado, encarcerado - possibilidades inscritas na ordem jurídica explícita -, enquanto na juridicidade subterrânea paralela e concomitante esse mesmo agente configurado inimigo é torturado e sumariamente eliminado: torna-se um matável, um homo sacer (AGAMBEN, 2010, p. 16).

\section{FENOMENOLOGIA DA VIOLÊNCIA}

A tese ideológica e criminalizante padrão sugere que o criminoso, esse sujeito desviante que não aceita as regras hegemonicamente impostas pelos grupos socias capazes de participar da produção normativa do Estado, é, por natureza (e aqui as razões invocadas vão do darwinismo social mais démodé, isto é, justificativas biológicas e genéticas, às exigências

\footnotetext{
1 Uma perspicaz ilustração das inúmeras contradições envolvidas entre dispositivos de segurança, desigualdades sociais radicais e violência, com especial referência aos países de "terceiro mundo", pode ser conferida em La zona [Zona do crime] (2007). Dirigido por Rodrigo Plá, o filme apresenta-nos a convivência sinistra de empobrecidas favelas e condomínios fechados, separados por muros, câmeras de vigilância e legalidades parelelas, transformado todos os demais habitantes da sociedade em mero entorno indesejável, revivendo cotidianamente segregações sócio-raciais que admitem as linhas de verdadeiros apartheid.

2 "Proponho-lhes nada menos que uma geral e maciça divisão do existente em dois grandes grupos ou classes:

de um lado, os seres viventes (ou, as substâncias), e, de outro, os dispositivos em que estes são incessantemente capturados. Isto é, de um lado, para retomar a terminologia dos teólogos, a ontologia das criaturas, e, de outro, a oikonomia dos dispositivos que procuram governá-las e guiá-las para o bem". "Generalizando posteriormente a já bastante ampla classe dos dispositivos foucaultianos, chamarei literalmente de dispositivo qualquer coisa que tenha de algum modo a capacidade de capturar, orientar, determinar, interceptar, modelar, controlar e assegurar os gestos, as condutas, as opiniões e os discursos dos seres viventes" (AGAMBEN, 2014, p. 39).
} 
de um culturalismo segregador que não admite a alteridade: o outro é socialmente aceito desde que concorde em se deculturalizar, assimilando sem tensões os padrões culturais impostos - é o caso da xenofobia), um ser incompatível com a sociedade, um infrator nato, que, portanto, merece punições e será alvo de estigmatizações e rotulações. Oficial ou informalmente esse sujeito é declarado inimigo, seja por sua violência atual e real ou pelo permanente potencial lesivo a ele atribuído. Sedimenta-se a percepção do inimigo como ser violento e a violência como objeto de contenção do direito penal; o silogismo, nesses termos, define o direito penal como o instrumento de contenção dos inimigos sociais.

Habituamo-nos a regimes de sensibilização de acordo com os quais somos capazes de perceber certos fenômenos como normais ou anômicos, ordeiros ou desviantes, regulares ou infratores, pacíficos ou violentos. Escravidão, segregação sócio-racial, machismo (etc.) são exemplos de fenômenos sociais que já estiveram inscritos na normalidade social ou, o que é dizer o mesmo noutro ângulo, já estiveram sob um regime de invisibilidade ${ }^{3}$. O visível e o invisível estão constantemente mediados por categorias morais, jurídicas e, igualmente, por categorias da percepção. Para que uma conduta seja percebida como violenta, errada ou criminosa são imprescindíveis instrumentos ou categorias cognitivas que permitam apreender o fenômeno, laçar luz, tornar o fato visível ${ }^{4}$.

O espetáculo horrorizante da violência produz um fascínio ambíguo de medo e retenção. Um fenômeno dessa magnitude tem a capacidade de atrair todas as atenções para o acontecimento imediatamente visível: torna-se imprescindível refazer o passo a passo dos criminosos ou desviantes, saber as circunstâncias minuciosamente, relegando ao segundo plano a reflexão destinada ao entendimento e à reação inteligente ao acontecimento ${ }^{5}$. Essa é a dimensão da violência subjetiva, que emerge, aparentemente sem mais nem menos, do âmago da normalidade cotidiana, provocando torções repentinas na configuração das identidades

3 Um exemplo bastante recente de sensibilidade seletiva pode ser reconhecido na diferença de tratamento entre o atentado assassino ao semanário Charlie Hebdo, na França, e o genocídio promovido pelo grupo Boko Haram, que vitimou, estima-se, duas mil pessoas, na Nigéria. Enquanto os holofotes lançaram-se sobre o crime cometido na redação do Charlie Hebdo, pouquíssima atenção foi depositada no caso nigeriano.

4 Jacques Rancière (2009, p. 16) afirma a existência de uma partilha do sensível, uma estética na base de toda política, capaz de configurar a experiência, constituir subjetividade política, definir e conformar quem é apto para a vida pública ou deve ser relegado ao ostracismo: "A partilha do sensível faz ver quem pode tomar parte no comum em função daquilo que faz, do tempo e do espaço em que essa atividade se exerce. Assim, ter esta ou aquela 'ocupação' define competências ou incompetências para o comum. Define o fato de ser ou não visível num espaço comum, dotado de uma palavra comum etc.".

5 O espetáculo da violência subjetiva, o fascínio do sangue, a exploração midiática e comercial da morte e do desastre são temas abordados na película Nightcrawler $[O \quad$ abutre $], \quad$ direção de $\quad$ Dan Gilroy, 2014 . 
simbólicas vigentes. A violência subjetiva tem o condão de magnetizar os olhares, reter e interditar a reflexão aguçada sobre o ocorrido. É imprescindível, todavia, notar a cumplicidade inevitável entre uma violência subjetiva e formas de violência objetiva operantes em concomitância. $\mathrm{O}$ foco exclusivo na violência subjetiva opera como álibi e bloqueia o acesso reflexivo à violência objetiva concorrente. Todo ato de violência, segundo Slavoj Žižek, é uma composição de três modos de violência: subjetiva, sistêmica e simbólica. O alerta "é que devemos resistir ao efeito de fascínio da violência subjetiva, da violência exercida por agentes sociais, indivíduos maléficos, aparelhos repressivos disciplinados e multidões fanáticas: a violência subjetiva é tão somente a mais visível das três" (ŽIŽEK, 2014, p. 25).

Enquanto a violência subjetiva irrompe de repente e fratura a realidade de uma maneira aparentemente irracional, a violência sistêmica, obnubilada, é insidiosa, não se manifesta espetacularmente como a violência subjetiva; a violência sistêmica encontra perfeita expressão nos movimentos especulativos do capital, capazes de provocar intensas catástrofes humanitárias sem que sejam percebidas como atos criminosos. Há uma cumplicidade dos excessos; o excesso de violência objetiva está intimamente atrelado a um excesso de violência subjetiva (como é o caso da violência sistêmica do capital, capaz de produzir multidões de excluídos e marginalizados, cúmplice da violência subjetiva mais em evidência, como os fundamentalismos étnico-religiosos de fundamento racista) (ŽIŽEK, 2014, p. 26).

A derradeira forma de violência, a simbólica, é inerente aos usos sociais da linguagem. Amiúde defende-se, na linha habermasiana, que a entrada na linguagem coincide com a negação da violência. Todavia a simbolização de uma coisa guarda sempre sua dimensão violenta, isso porque a linguagem tem a aptidão de elidir a complexidade do objeto, simplificando-o, reduzindo-o a mera caricatura (ou estereótipo) do que realmente é 6 . A linguagem tem o dom de constituir essência para as coisas e para as pessoas, ela é essencializante. Sob o pressuposto da isenta descrição de um objeto, o que a linguagem faz é

6 Žižek (2014, p. 59-60) afirma que "a linguagem simplifica a coisa designada, reduzindo-a a um simples traço" e aduz um exemplo significativo: "quando chamamos o ouro de 'ouro', extraímos violentamente um metal de sus textura natural, investindo nele nossos sonhos de riqueza, poder, pureza espiritual etc., ao mesmo tempo que nada disso tem relação com a realidade imediata do ouro". 
constituí-lo em consonância com a "descrição" apresentada7 .

Se a tese ideológica assevera que o criminoso é um inimigo da sociedade, porque é um ser violento, não podemos ser seduzidos pela exclusiva dimensão subjetiva da violência; esta é indissociável das contradições de um desenvolvimento social excludente que é forma de violência (sistêmica) inscrita no imaginário social como situação de normalidade, portanto despercebida. Tampouco é adequado ser displicente aos efeitos performativos da linguagem, pois o que constitui o inimigo como inimigo não são seus atos senão a intrincada teia de discursos, imagens e símbolos outorgados a uma pessoa que, capturada por dispositivos jurídicos e midiáticos, é fabricada como sujeito criminoso. O mitologema político do inimigo só pode ser desmistificado colocando em crise as operações de simbolização:

[...] quando percebemos algo como um ato de violência, sua definição enquanto tal é orientada por um critério que pressupõe o que seria a situação não violenta 'normal' - ao passo que a forma mais alta de violência é justamente a imposição desse critério por referência ao qual certas situações passam a ser percebidas como 'violentas'. É por isso que a própria linguagem, o meio por excelência da não violência e do reconhecimento mútuo, implica uma violência incondicional (ŽIŽEK, 2014, p. 62).

A violência não é uma realidade ôntica, um ente; é um predicado extrinsicamente atribuído. A determinação do ato violento está condicionada ao reconhecimento, a um regime de (in)visibilidade sobredeterminante, capaz de iluminar e de obnubilar. A caracterização do ato violento é um procedimento normativo; é imprescindível imputar ou fazer incidir uma carga semântico-simbólica que confere significado ao feito. É impossível enumerar os atos violentos, visto que se trata de qualidade atribuível a posteiori, uma essenciação retroativa. Violência é violência percebida, o que significa que exige uma espessura de pressuposições compartilhadas. Daí a necessidade de a ideologia criminalizante estabelecer uma dominação simbólica ritimada pela ubiquidade do medo e retroalimentada espontaneamente pela cumplicidade obsequiosa dos agentes sociais envolvidos. A espontaneidade ou imediatez da conduta dos agentes submersos na dominação simbólica é produto de noções inculcadas que, ao não solicitar reflexão, engendram uma falência imaginária que obsta cogitar outras

7 "Foi Heidegger quem elaborou esse traço no nível ontológico-formal quando, ao ler a "essência ou Wesen" como um verbo ("essenciar"), apresentou uma concepção desessencializada da essência. Tradicionalmente, a "essência" se refere a um núcleo estável que garante a identidade de uma coisa. Para Heidegger, a "essência" é algo que depende do contexto histórico, do desvelamento epocal do ser que acontece na e através da linguagem. Esta é por ele chamada de "casa do ser". Sua expressão "Wesen der Sprache" não significa a "essência da linguagem", mas o "essenciar", essa criação de essências que é o trabalho da linguagem" (ŽZŽEK, 2014, p. 63). 
interpretações possíveis para o ato presenciado $^{8}$. Para que essa alquimia capaz de conformar e limitar a percepção funcione, toda estrutura social é recrutada, gerando consciências que mimetizem as estruturas sociais e que, portanto, não sejam hábeis a perceber a arbitrariedade das instituições e de seus ideários (BOURDIEU, 2011a, p. 169).

\begin{abstract}
A violência simbólica é essa violência que extorque submissões que sequer são percebidas como tais, apoiando-se em "expectativas coletivas", em crenças socialmente inculcadas. Como a teoria da magia, a teoria da violência simbólica apoia-se em uma teoria da crença ou, melhor, em uma teoria da produção da crença, do trabalho de socialização necessário para produzir agentes dotados de esquemas de percepção e de avaliação que lhe farão perceber as injunções inscritas em uma situação, ou em um discurso, e obedecê-las (BOURDIEU, 2011a, p. 171).
\end{abstract}

O empreendimento criminalizante conjuga esforços de diversos campos, tece uma rede linguística e simbólica a partir de múltiplos discursos. Sinopticamente: há a força da moral, que justifica a criminalização a partir de valores (supostamente) universais, que vê no criminoso uma violação da consciência coletiva; a ideologia está igualmente presente com a manifestação de diversas motivações, em geral associando taxas mais abrangentes de encarceramento com maior segurança ou menor medo para a população; finalmente, é imprescindível colocar em pauta o direito, responsável pela proliferação de normas jurídicopenais destinadas a viabilizar os anseios morais e ideológicos de criminalização. Moral, ideologia e direito convergem em uma violência simbólica destinada a produzir crenças, inculcar noções e extorquir conivência. Aquele que se submete imediatamente aos ditames exigidos, sem cálculo ou raciocínio, tende a extrair os maiores benefícios decorrentes da aprovação da consciência coletiva "por ter feito, como se fosse natural, algo que era, como se diz, a única coisa a fazer, mas que ele poderia não ter feito" (BOURDIEU, 2011a, p. 171). A alquimia produzida nessa cadeia discursiva dissemina o convencimento de que o criminoso não apenas cometeu uma infração qualquer, mas o cometimento da infração em si delata a essência do infrator, uma essência criminosa que dissolve a humanidade do infrator, desse momento em diante rotulado de inimigo.

8 A primeira propriedade da economia de trocas simbólicas envolvida na constituição de imaginários sociais está na dualidade entre a verdade subjetiva e a verdade objetiva: "Essa dualidade torna-se possível, e pode ser vivida, através de uma espécie de self-deception, de automistificação. Mas essa self-deception individual é apoiada por uma self-deception coletiva, um real desconhecimento coletivo, cujo fundamento se inscreve nas estruturas objetivas (a lógica da honra, que comanda todas as trocas - de palavras, de mulheres, de homicídios etc.) e nas estruturas mentais, excluindo a possibilidade de pensar e de agir de outro modo" (BOURDIEU, 2011a, 161). 
O capital simbólico, como ente percebido, é comum a todos os membros do grupo; é objeto de estratégias coletivas de conservação e ampliação e de planejamentos individuais de aquisição. A distribuição do capital simbólico no espaço social promove as distinções e os agrupamentos diferenciais de acordo com a concentração percebida de capital (BOURDIEU, 2011a, p. 171-2). É possível, nesses termos, conceber o criminoso como carente ou desprovido de capital simbólico, o que o coloca em um espectro do espaço social muito distante dos agentes e dos grupos reconhecidos por acumular muito capital simbólico. Em geral, aqueles agentes aptos a influenciar a moral vigente, a criar assertivas ideológicas e a controlar a produção normativa do direito, são agentes que portam maciça espessura de capital simbólico. Como aduz Bourdieu, as categorias de percepção tendem a ser mais homogêneas entre grupos que ocupam a mesma posição no espaço social e, inversamente, costumam se diversificar quanto maior for a distância entre uma posição social e outra. Já que a distribuição no espaço social se dá conforme o acúmulo de capital simbólico, os agentes da normatividade, detentores de capital simbólico, e os infratores, destituídos de capital simbólico, estão muito disntantes uns dos outros. Por conseguinte não se criam laços de afinidade, na medida em que até mesmo as categorias de percepção dos fenômenos estão apartadas e são incomunicáveis.

A carência ou o acúmulo de capital não são percebidos segundo essa descrição econômica, mas em termos de essências percebidas. Os detentores de capital simbólico identificam a si próprios como inerentemente diferentes daqueles destituídos de capital simbólico, o que favorece a essenciação dos agentes. Zaffaroni descreve o fortalecimento da "periculosidade sem delito", um procedimento jurídico que não se limita a reprovar condutas de agentes sociais, mas a conduta em si tem o condão de capturar e de definir o indivíduo como um todo, cria-lhe uma essência criminosa, ou, como alerta Zaffaroni, "por trás de toda individuação de um inimigo há um mito que lhe pretende conferir um caráter ôntico" (ZAFFARONI, 2011, p. 105). O verdadeiro risco, permanentemente à espreita, é regressar ao direito penal do autor e ao seu típico afã de encontrar situações objetivamente periclitantes, indivíduos incapazes de convívio comunitário, merecedores de punição e controle?

9 Para Günther Jakobs, "o direito penal deveria habilitar o poder punitivo de uma maneira para os cidadãos e de outra para os inimigos, reservando o caráter de pessoa para os primeiros e considerando não-pessoas os segundos, confinando, porém, esta habilitação num compartimento estaque do direito penal, de modo que todo o resto continue funcionando de acordo com os princípios do direito penal liberal" (ZAFFARONI,

2011, p.156). 
$\mathrm{Na}$ fenomenologia do crime, a reprovação da conduta infratora, à primeira vista tão natural e espontânea, revela-se, ao ultrapassarmos o torpor espetacular da violência subjetiva, paulatinamente constituída segundo categorias de percepção que mimetizam estruturas sociais. Aqui se encontra a dificuldade de driblar o ideário bem assentado que constantemente flerta com a identificação do criminoso como inimigo da sociedade, pois são disposições arraigadas além da consciência, inculcadas como crenças desconhecidas pela consciência, mas disciplinadamente observadas na prática. É nesse sentido que Žižek assevera que uma das facetas mais importantes, e ignoradas, da violência é a imposição de critérios a partir dos quais as condutas serão espontaneamente percebidas como violentas. O que vale para a violência é igualmente aplicável ao crime, na medida em que também há critérios, socialmente elaborados, que permitem perceber uma conduta como criminosa. Não há, em suma, nada de natural ou espontâneo na percepção da violência, tampouco na do crime. Em ambos os casos, para serem apreendidos como tais, dispositivos devem operar normativamente para anexar um significado a um comportamento que, isoladamente, não tem nenhum significado pré-definido ou tem todos os significados possíveis.

\section{A PRODUÇÃO DO DESVIO}

As sociedades complexas atuais são permeadas de inúmeras normatividades, variam no espaço e transmutam-se com o passar do tempo. Basta que um grupo social consiga ser coeso, congregue indivíduos e, a depender do grau de estabilidade, formule uma ideário menos ou mais amplo para que uma normatividade seja formulada. $\mathrm{O}$ ponto em comum das regras formuladas pelos grupos é tão somente o caráter normativo visto que, evidententemente, cada uma dessas normatividades tem sua própria abrangência (ainda que cada grupo capaz de produzir uma normatividade própria frequentemente se convença - a partir de um sem número de justificações, racionalizações e crenças - da não particularidade de suas normas, ou seja, amiúde a pretensão universalista está atrelada à produção normativa). Tampouco equivalem-se em força: a dimensão do poder (capacidade de impor suas regras independente do consenso ou da discordância daqueles a elas submetidos) é indissociável de qualquer normatividade, o que as hierarquiza em larga desigualdade.

Revista de Criminologias e Políticas Criminais | e-ISSN: 2526-0065 | Minas Gerais | v. 1 | n. 2 | p. 1 - 20 | Jul/Dez. 2015. 
O direito do Estado é apenas uma dentre a miríade de normatividades simultaneamente vigentes no tecido social; é claro que se trata de uma normatividade amparada nas intituições, no poder coercitivo (monopólio da violência) e em um arcabouço de discuros legitimadores. Todas essas circunstâncias investem a normatividade estatal de um prestígio que favorece a obediência consensual e, caso a deferência falhe, o aparelho repressivo está permanentemente em prontidão para satisfazer as "razões de Estado". O principal alicerce punitivo da normatividade produzida pelo Estado é o direito penal, o único apto a legitimamente suprimir o direito fundamental à liberdade de locomoção, o que, conjuntamente, obsta a satisfação de inúmeros outros desejos.

O criminoso é socialmente reconhecido como aquele que viola normatividades admitidas como legítimas. No interior da doutrina penal legalista, o crime é o resultado da infração de um preceito legal, especialmente os contidos no Código Penal, porém o senso comum tem suas próprias impressões a respeito do criminoso e é capaz de formular um conjunto de exigências concorrentes às do Estado. Não raro há condutas definidas no Código Penal como criminosas que não encontram plena consistência nos juízos normativos do senso comum - pode ser o caso de crimes ambientais ou, em menor medida, econômicos, que não suscitam a intensa aversão moral provocada por crimes contra a vida ou contra o patrimônio. O inverso é igualmente verificável, é corriqueiro que o senso comum reclame da insuficiência das leis penais, seja na exigência de penas mais gravosas, seja na demanda de novas tipificações. Há, portanto, uma concorrência entre atores sociais em torno das definições de crime e de criminoso. Essa disputa semântica, profundamente política, está presente também no interior das teorias criminológicas e se revela claramente na passagem do paradigma etiológico para o labeling approach.

O paradigma etiológico encontra-se no cerne da escola positivista, cujo objetivo é mapear as causas do comportamento criminoso com o intento de (re)adequar o indivíduo para o convívio social "normal". A criminologia positivista, embora remeta a um anacrônico saudosismo darwinista, permanece atual, seja porque estudos biológico-genéticos continuam sendo elaborados, mas sobretudo porque a criminologia positivista deslocou o foco, lateralizando os fatores biológicos em favor de fatores sociais (as condições sócias que beneficiam o aparecimento do indivíduo criminoso). Permanece, todavia, o núcleo do pensamento criminológico positivista, concentrado no paradigma etiológico (a pretensão de encontrar causas, biológicas ou sociais, para a criminalidade e para o indivíduo delinquente) e no correcionalismo (a observação clínica dos comportamento do delinquente com vistas a 
corrigi-lo, readequá-lo ao convívio social). A vertente criminológica que coloca em crise esses pressupostos positivistas será o labelling approach ou paradigma da reação social, em sua defesa da inadequação das buscas pelas causas do crime, à medida que este não tem uma existência pré-constituída anterior à definição legal de quais condutas serão tachadas de criminosas (BARATTA, 2013, p. 30).

Para as teorias do labeling approach o crime nada tem de intrinsecamente danoso ou imoral, o ato considerado criminoso é muito semelhante ao ato dito normal (não criminoso), a diferença é introduzida por uma definição legal. Enfatiza-se que o crime não pode ser conhecido se tomado em separado, o crime é o resultado da incidência de agências sociais de controle, que vão desde as normas jurídicas do Estado (especialmente o direito penal) às instituições de controle, como a polícia, a magistratura, as instituições penitenciárias. A preocupação recai não no crime como ato intrinsecamente mau, mas nos processos de criminalização, por intermédio dos quais um indivíduo é declarado criminoso. A virada epistemológica viabilizada pelo labeling approach está em deslocar as indagações em torno do "crime" e do "criminoso" para o problema da "criminalização": o crime não é uma realidade pré-constituída a qualquer agenciamento das instituições sociais, é, ao contrário, o produto da intervenção normativa das instituições de controle social (BARATTA, 2013, p. 857). Os processos de atribuição do rótulo "criminoso" a um comportamento ou agente não se limita às operações das instituições oficiais, os processos de definição levados a cabo pelo senso comum, anterior à intervenção das agências oficiais, devem ser levados em consideração (BARATTA, 2013, p. 94).

O giro epistemológico empreendido pelo labeling deixa de presumir a onticidade do crime e denega a ideia de um criminoso nato, bem como o determinismo que une circunstâncias sociais ao crime. Tais delineamentos impelem a inquirir como um comportamento passa a ser interpretado ou definido como crime ou desvio. É imperioso investigar qual é a magia que opera essa alquimia. As modernas sociedades possuem diversos grupos sociais e isso faz com que, amiúde, obedecer as regras impostas por um grupo seja desrespeitar as regras que outro grupo pretende impor; neste caso a desviância é inevitável. O fato central acerca do desvio é que ele é produto da sociedade: não no sentido de que fatores socioeconômicos convergem e inclinam certos sujeitos à desviância, mas porque são grupos sociais que criam e impõem as regras vigentes, de tal modo que o desvio já está predeterminado na regra (BECKER, 2008, p. 21-2). 
Desse ponto de vista, o desvio não é uma qualidade do ato que a pessoa comete, mas uma consequência da aplicação por outros de regras e sanções a um 'infrator'. O desviante é alguém a quem esse rótulo foi aplicado com sucesso; o comportamento desviante é aquele que as pessoas rotulam como tal (BECKER, 2008, p. 22).

Já que o desvio é o resultado da imposição de regras por certos grupos sociais, não se pode supor que a pessoa rotulada como desviante de fato o é, isso porque o processo de rotulação admite falhas: pessoas podem ser reconhecidas como desviantes sem que tenham violado qualquer regra. Tampouco se deve supor que somente aqueles rotulados violaram regras, porque muitos infratores podem escapar da rotulação e, por isso, não aparecer no rol dos atores considerados desviantes ${ }^{10}$. Na medida em que o desvio resulta da interação dos impositores das regras e dos supostos violadores delas, não é adequado atribuir o desvio a alguma propriedade ínsita ao indivíduo. O que as pessoas desviantes verdadeiramente partilham não é uma essência e sim o próprio rótulo, o fato de todas terem sido alvo de rotulação: o desvio é "o produto de uma transação que tem lugar entre algum grupo social e alguém que é visto por esse grupo como infrator de uma regra" (BECKER, 2008, p. 22). Howard Becker sumariza os fatores envolvidos no processo que predica o comportamento como desviante:

\footnotetext{
o desvio não é uma qualidade simples, presente em alguns tipos de comportamento e ausente em outros. É antes o produto de um processo que envolve reações de outras pessoas ao comportamento. O mesmo comportamento pode ser uma infração das regras num momento e não em outro; pode ser uma infração quando cometido por uma pessoa, mas não quando cometido por outra; algumas regras são infringidas com impunidade, outras não. Em suma, se um dado ato é desviante ou não, depende em parte da natureza do ato (isto é, se ele viola ou não alguma regra) e em parte do que outras pessoas fazem acerca dele (BECKER, 2008, p. 26).
}

Em nossas sociedades, as pessoas, de um modo geral, caracterizam-se pela adesão paulatina e constante às convenções e regras postas pelas instituições reconhecidas. Mesmo que os desejos desviantes ocorram à maioria das pessoas, a generalidade erige bases firmes na convencionalidade que permitem abandonar seus anseios anômicos. Diante da pessoa que comete o desvio, é inadequado buscar refletir como pode aquele ator possuir o desejo desviante, pois este é presente também naqueles que se atêm à convencionalidade. $\mathrm{O}$ questionamento cabível concerne a como a pessoa desviante foi capaz de desatar os laços convencionais impostos pelas normas e pelas instituições (BECKER, 2008, p. 38).

10 "O simples fato de uma pessoa ter cometido uma infração a uma regra não significa que outros reagirão como se isso tivesse acontecido. (Inversamente, o simples fato de ela não ter violado uma regra não significa que não possa ser tratada, em algumas circunstâncias, como se $\quad$ o tivesse $\quad$ feito.)" 
O infringir eventual de uma regra pode levar o indivíduo a um contato com uma subcultura desviante, pode acontecer que ele aprenda os prazeres envolvidos naquela atividade e isso o faça aderir ao grupo. A adesão à subcultura desviante pode se consolidar quando o indivíduo é descoberto e publicamente se lhe impõe um rótulo concernente àquele desvio ("bicha", “maconheiro", "pervertido"...). Consequentemente, a pessoa passa a ser reconhecida pelo rótulo que lhe foi socialmente imposto e com isso podem se passar transformações na identidade da pessoa: a estigmatização tem efeitos subjetivadores que promovem o autorreconhecimento consoante o rótulo. "A posse de um traço desviante pode ter um valor simbólico generalizado, de modo que as pessoas dão por certo que seu portador possui outros traços indesejáveis presumivelmente associados a ele" (BECKER, 2008, p. 43). O rótulo de desviante desdobra-se sobre toda a existência do indivíduo, esgueirando-se até mesmo sobre as dimensões da existência que nenhuma relação têm com o desvio cometido; $o$ rótulo captura a vida.

Tratar uma pessoa como se ele fosse em geral, e não em particular, desviante produz uma profecia autorrealizadora. Ela põe em movimento vários mecanismos que conspiram para moldar a pessoa segundo a imagem que os outros têm dela. Em primeiro lugar, após ser identificada como desviante, ela tende a ser impedida de participar de grupos mais convencionais, num isolamento que talvez as consequências específicas da atividade desviante nunca pudessem causar por si mesmas caso não houvesse o reconhecimento público e a reação a ele (BECKER, 2008, p. 44).

Após ser publicamente reconhecido como desviante, a reação social (punitiva) pode agravar o desvio: "o tratamento dos desviantes lhes nega os meios comuns de levar adiante as rotinas da vida cotidiana acessíveis à maioria das pessoas. Em razão dessa negação, o desviante deve necessariamente desenvolver rotinas ilegítimas” (BECKER, 2008, p. 45). O desvio que se passa em uma esfera da vida, após ser publicamente reconhecido e rotulado, reverbera e provoca perturbações noutras esferas que se encontravam originalmente alheias. A estabilização da situação desviante ocorre quando o indivíduo adere a uma subcultura desviante ou se dá conta de que já faz parte de uma, fato que ressoa na autoidentidade do sujeito. Os membros de uma subcultura desviante compartilham o desvio, isso viabiliza um sentimento de pertença, fornece discursos que legitimam suas práticas e articulam estratégias de rotinas alternativas, à medida que as rotinas convencionais foram obstadas aos desviantes (BECKER, 2008, p. 45-8).

O giro epistemológico engendrado pela criminologia inspirada no labeling approach viabiliza um olhar não-essencialista, ou sociológico, sobre o fenômeno do desvio e contesta a onticidade do inimigo social. Um olhar sociológico revela, na ocorrência do desvio, a 
inevitável e correlata presença de um agente impositor de regras, movido por valores e interesses, ou seja, não é, por conseguinte, neutro e imparcial. Na medida em que a gênese do desvio (ou do crime) se dá quando a conduta figura como caso particular dedutível de uma proposição abstrata socialmente reconhecida como norma, é imprescindível investigar as características do agente apto a impor a norma. Debruçar-se sobre as circunstâncias e sobre as motivações do impositor de regras desconstitui o discurso legitimador defensor da objetividade dos valores e da universalidade dos desejos tutelados pela norma. O impositor não é um arquetípico sujeito transcendental, age segundo interesses, valores morais, preconceitos e emoções ${ }^{11}$.

A tradicional epistemologia criminológica tomava como objeto entender o crime e identificar os caracteres ínsitos ao criminoso $^{12}$. A criminologia crítica contemporânea, assumindo feições marcadamente sociológicas, insiste que concentrar todos os holofotes no criminoso ou desviante é um equívoco epistemológico ou, meramente, uma iniciativa ideológica convenientemente desisteressada da complexidade do fenômeno do desvio e do crime. Enfocar o criminoso ou o crime é concentrar-se no infrator e na infração da regra, elidindo uma dimensão crucial para a compreênsão desses fenômenos: a regra é produzida por um impositor, um empreendedor moral, que age seletivamente. Entender o crime e, assim, deixar de lado a visão do criminoso como inimigo da sociedade, envolve reconhecer que o impositor da regra tem um papel constituinte na fenomenologia do crime. Os impositores de regras, para justificar sua posição, têm de demonstrar que o problema existe, representa uma ameaça e que as regras que se pretende impor darão conta de sanar esse mal. O impositor tem larga margem para administrar a maneira como imporá as regras, cria planos estratégicos de ação e prioridades e é nesse momento de definição de estratégias que alguns infratores de regras que, segundo os padrões supostamente universais deveriam ser punidos, logram, em virtude de sua influência, escapar da punição (seja antes ou depois da detenção) - eis mais uma dimensão da seletividade da imposição de regras ou punição (BECKER, 2008, p.161-4).

\footnotetext{
11 É notável que Howard Becker (2008, p. 151) proponha nomear o impositor de regras de empreendedor moral, já que se trata de investir esforços em defesa de um empreendimento social, uma tentativa de compor a estrutura moral, emocional e perceptiva de toda a sociedade. Eis a notificação do autor: "onde quer que regras sejam criadas e aplicadas, deveríamos estar atentos quanto a possível presença de um indivíduo ou grupo empreendedor. Suas atividades podem ser propriamente chamadas de empreendimento moral, pois o que empreendem é a criação de um novo fragmento da constituição moral da sociedade, seu código de certo e errado. Onde quer que regras sejam criadas e aplicadas, deveríamos esperar encontrar pessoas que tentam arregimentar o apoio de grupos assemelhados e usam os meios de comunicação disponíveis para desenvolver um clima de opinião favorável. Onde eles não desenvolvem esse apoio, podemos esperar o fracasso do empreendimento".

12 É suficiente recordar que uma das obras paradigmáticas da criminologia etiológica recebeu o nome L'uomo delinquente [O homem delinquente (2007)]. Vê-se, aqui, uma manifestação sintomática de como o objeto da criminologia era a pessoa criminosa; um empreendimento cognoscitivo distante do labeling approach e das criminologias críticas.
} 


\section{CONCLUSÃO}

O direito, como sistema simbólico, é uma estrutura estrurante e estruturada. É estruturante na medida em que é capaz de impor princípios de conhecimento e de classificação do mundo, taxonomias que permitem agrupar os fenômenos segundo afinidades de sentido construídas. O direito é uma estrutura social que induz uma conformação subjetiva ou de percepção; a lei penal produz o criminoso e interfere na produção imaginária do inimigo na medida em que o direito é estrutura que conforma, por mimetização, as consciências. É estrutura estruturada, ou seja, à medida que não são estruturas apriorísticas inscritas na consciência e sim estruturas mundanas produzidas e internalizadas, é preciso que haja uma estruturação das estruturas, mobilizações sociais que produzam e alimentem as estruturas (BOURDIEU, 2011b, p. 4-5). Está em disputa o monopólio da violência simbólica legítima, a capacidade de impor taxonomias para a realidade. A classe dominante é uma posição no espaço social que busca elidir sua dominação por intermédio da produção simbólica (BOURDIEU, 2011b, p. 8).

O poder soberano, como revelou Agamben, tem a composição de uma exceção, a aptidão de estabelecer um limiar de indiscernibilidade topológica entre dentro e fora, uma estrutura em que o estado de natureza, amiúde teorizado como uma instância estaticamente extrínseca à soberania, reaparece como um momento constitutivo da soberania, como estado de exceção (AGAMBEN, 2010, p. 43). A soberania extrai seu poder da relação de abandono que mantém com os súditos, da sua capacidade de lançar a vida humana em uma esfera de indiscernibilidade em que toda vida, mediante decisão soberana, pode tornar-se vida matável, homo sacer, isto é, vida que pode ser eliminada sem que se constitua o crime de homicídio ou um sacrifício sagrado. Soberano e homo sacer são figuras especulares ou correlatas; o "soberano é aquele em relação ao qual todos os homens são potencialmente homines sacri e homo sacer é aquele em relação ao qual todos os homens agem como soberanos" (AGAMBEN, 2010, p. 86).

A disputa em torno do poder de punir é perseguida por agentes sociais que batalham pelo monopólio da legitimidade da violência simbólica, que se exerce em múltiplas esferas da vida, mas que encontra no poder soberano estatal um espaço privilegiado, em que a desmesura do poder é capaz de atribuir ou destituir a humanidade. $\mathrm{O}$ criminoso, esse produto socioestatal, juridicamente fabricado (isto é, interpelado por normatividades sociais e pela normatividade do Estado, o direito), está sempre à beira, no liminar, de ser convertido em 
inimigo da sociedade. O poder soberano, ao depreender sua vitalidade da relação de abandono ou de exceção, está sempre produzindo homines sacri e, por essa condição incomensurável, é objeto de disputas entre grupos e agentes que almejam pautar a dominação simbólica, estabelecer os critérios taxonômicos, essa forma mágica de violência simbólica, que assegura ou destitui a humanidade do vivente. O certo é que essa máquina governamental, como a espada de Dâmocles, permanece espectralmente presente, constantemente na iminência da capturar a vida, essenciá-la por intermédio da alquimia da linguagem, imputar-lhe o rótulo de desviante, abandoná-la nos vazios constitutivos do poder. A tarefa da crítica é solapar o desempenho dessa máquina.

\section{REFERÊNCIAS BIBLIOGRÁFICAS}

AGAMBEN, Giorgio. Homo sacer: o poder soberano e a vida nua I. $2^{\mathrm{a}}$ ed. Belo Horizonte: UFMG, 2010.

, O amigo \& O que é um dispositivo? Chapecó: Argos, 2014.

BARATTA, Alessandro. Criminologia crítica e crítica do direito penal: introdução à sociologia do direito penal. Rio de Janeiro: Revan: Instituto Carioca de Criminologia, 2013.

BECKER, Howard S. Outsiders: estudos de sociologia do desvio. Rio de Janeiro: Zahar, 2008.

BOURDIEU, Pierre. O poder simbólico. Lisboa: Edições 70, 2011 b.

Razões práticas: sobre a teoria da ação. $11^{\mathrm{a}}$ ed. $2^{\mathrm{a}}$ reimp. Campinas: Papirus, $2011 \mathrm{a}$.

KELSEN, Hans. Teoria pura do direito. $8^{\mathrm{a}}$ ed. São Paulo: WMF Martins Fontes, 2009.

LOMBROSO, Cesare. O homem delinquente. São Paulo: Ícone, 2007.

RANCIÈRE, Jacques. A partilha do sensível: estética e política. $2^{\mathrm{a}}$ ed. São Paulo: Editora 34; EXO experimental org.: 2009.

ZAFFARONI, E. Raúl. O inimigo no direito penal. $3^{\text {a }}$ ed. Rio de Janeiro: Revan: Instituto Carioca de Criminologia, 2011.

ŽIŽEK, Slavoj. Violência: seis reflexões laterais. São Paulo: Boitempo, 2014. 